\title{
O strujama suvremenoga islama, svetom ratu i čitanju Kurana
}

\author{
Blerim Latifi*, Kristë Shtufi**
}

\begin{abstract}
Sažetak
Potresni masakri izvršeni tijekom građanskoga rata u Siriji i Iraku, od strane raznih grupa, posebno onih udruženih pod amblemom ISIS-a (Islamske države Iraka i Sirije) bili su povod da se mnogi poznavatelji, klerici i islamski teolozi $i$ drugi, širom svijeta, uključe u diskursnom nastojanju kako bi uspostavili bilo kakve veze između kuranskih tekstova i ratnoga djelovanja militanata te države, samoproglašene kao novi kalifat. To nastojanje inzistira na ideji da se u kuranskom tekstu ne mogu naći nikakva opravdanja za zločine ISIS-a ni argumenti koji podržavaju pretenzije njegovih militanata da ono što čine u Siriji i Iraku nije ništa drugo nego ispunjavanje kuranske obveze, koja je u islamskoj vjeri poznata kao obveza džihada (jihad). Tko je tu u pravu? Da bi se dao odgovor na to pitanje, svakako ne i definitivno, potrebno je razmotriti niz pitanja. Prvo pitanje tiče se konteksta glavnih strujanja u suvremenom islamu. To će nam omogućiti ustanovljavanje mjesta koje grupe kao što su ISIS i Al Nusra (proizišla kao ogranak Al Qaide) zauzimaju u islamskoj doktrinarnoj tipologiji i topologiji. Drugo pitanje tiče se same koncepcije džihada. Treće je pitanje odnosa samoga kuranskoga teksta s ratom, nasiljem i mogućim načinima čitanja toga teksta. Drugo i treće pitanje omogućavaju nam da sagledamo do koje su mjere utemeljene pretenzije tih grupa da njihovi pokreti predstavljaju oživljavanje autentičnoga islama..
\end{abstract}

Ključne riječi: suvremeni islam, Kuran, nasilje, Weber, Hegel, kontekstualizacija

\section{Uvod}

$\mathrm{U}$ ovom se članku analizira okolnost da danas u islamskom svijetu postoji nekoliko struja islama, među kojima je jedna od struja s izravnim utjecajem na fenomen terorizma, a to je salafistička struja. U članku se utvrđuje da džihad, sveti rat $\mathrm{u}$ islamu, i nasilje nad drugim vjerskim skupinama potencijalno postoje u surama Kurana, osobito u onima koje pripadaju Muhamedovu proročanstvu

* Doc. dr. sc. Blerim Latifi, Filozofski fakultet Sveučilišta u Prištini. Adresa: Ulica Eqrem Çabej,br. 21, 10000 Priština, Kosovo. E-adresa: blerimlatifi5@gmail.com

** Doc. dr. sc. Kristë Shtufi, Filozofski fakultet Sveučilišta u Prištini. Adresa: Ulica Eqrem Çabej,br. 21, 10000 Priština, Kosovo. E-adresa: kriste.shtufi@uni-pr.edu 
u razdoblju u Medini. Te sure svojim pozivima proturječe surama razdoblja proročanstva Muhameda u Meki, koje su više duhovnoga i tolerantnoga karaktera. U članku se također podupire teza Maxa Webera o islamu kao religiji ratnika. Naša je teza da jedina mogućnost izbjegavanja nasilnoga potencijala sadržanoga u kuranskom tekstu jest hegelovsko i kontekstualno čitanje toga teksta. To čitanje ponajprije podrazumijeva znanstvenu i filozofsku kritiku toga teksta i otkriće njegove antropogeneze.

\section{Oficijelni i pučki islam}

Islam, zajedno s judaizmom i kršćanstvom, spada u grupu takozvanih „abrahamskih religija". Te se religije tako nazivaju jer sve tri sadržavaju priču o proroku Abrahamu i njegovoj povijesti odnosa s Bogom, povijesti koja služi kao začeće ideja koje te religije promiču u vezi s onim što je poznato kao moralni poredak svijeta, čiji je pretpostavljeni branitelj svemogući i svemilosrdni Bog.

Sve te tri religije u svojoj su srži monoteistične, imaju jednaku predodžbu Boga, ali se suprotstavljaju jedna drugoj u trenutku kada trebaju opravdati vlastito postojanje. Budući da je judaizam najstariji od njih, kršćanstvo i islam pravdaju sebe idejom da je judaizam deformirana i korumpirana monoteistička religija. U tom kontekstu, u kršćanskoj se tradiciji vjeruje kako je Krist došao da bi obnovio zakon koji je Bog putem Mojsija dao židovima te da bi očistio hramove od korupcije, degeneracije i grijeha. U Evanđelju po Mateju Krist kaže svojim sljedbenicima: »Ne mislite da sam došao ukinuti Zakon ili Proroke! Nisam došao ukinuti, nego ispuniti«(Mt5:17). Kasnije je i islam našao slično samoopravdanje. Muhamedova misija nije da utemelji novu religiju, nego da obnovi autentični monoteizam, koji su deformirali judaizam i kršćanstvo. Pravdanje sebe negiranjem drugoga, tijekom povijesti, poslužilo je kao stalan izvor konflikata među tim religijama. Tim je konfliktima snažno doprinijela također univerzalistička pretenzija kršćanstva i islama. Što znači ta pretenzija, vidjet ćemo prilikom tretiranja problema džihada (svetoga rata).

U suvremenom kontekstu, islam predstavlja jednu od velikih svjetskih religija, koja svojim velikim prisustvom na tri kontinenta čini bitan utjecaj na živote milijuna ljudi od Jakarte do Istambula. Raširen u različitim geografskim i kulturnim zonama, prirodno je da je islam pretrpio brojne praktične modifikacije, i kao posljedicu kulturne interakcije. To je ponukalo danas na razmišljanja kako ne postoji jedan jedini islam, nego nekoliko njih. U tom kontekstu jedan od poznatih proučavatelja islama Jacques Waardenburg $(2002,13)$ smatra da se početna i minimalna razlika može ustvrditi između službenoga i pučkoga islama. Službeni islam obuhvaća norme i doktrine za koje se smatra da su valjane za sve muslimane, a posljedično tomu i kriterije na temelju kojih se određuje identitet muslimana. Artikulacija toga islama proizvod je učenjaka koji posjeduju saznanja o svetim spisima, tradiciji zakonu (šerijatu). Tako, može se reći da je službeni islam u stvari normativni islam. 
Za razliku od njega, pučki islam predstavlja drugačiju realnost. On predstavlja sve one načine i forme življenja islama u lokalnim etničkim i kulturnim kontekstima: »On je živa empirijska realnost unutar tradicije lokalnih skupina «(Waardenburg, 2002, 13). ${ }^{1}$

Između te dvije vrste islama, prema Waardenburgu, često može biti tenzija, jer službeni islam težito mu da njegove norme imaju univerzalnu vrijednost, a pučki islam, po samoj svojoj prirodi, u sebi sadržava elemente koje službeni islam nastoji eliminirati. To su elementi neislamskih lokalnih kultura, koji se kroz društvene interakcije integriraju u islamske vjerske prakse.

Konceptualno, te dvije vrste islama razvijaju različite odnose s vjerskom tolerancijom. Pretenzije na univerzalnu valjanost vodi normativni islam u netolerantan stav naspram ostalih vjerskih tradicija, a pučki se islam, u suživotu s tim tradicijama, prirodno razvija u kulturu vjerske tolerancije.

Interesantnu interpretaciju raznih oblika islama iznosi poznati filozof i teolog Tariq Ramadan. Njegova interpretacija nastoji integrirati forme normativnoga i pučkoga islama unutar koncepcije onoga što Ramadan naziva „islamska civilizacija”. Realnost te civilizacije se izražava na trima razinama. Na prvoj razini, onoj temeljnoj, islam je jedinstven, u smislu da se svi muslimani, bilo oni na Istoku ili Zapadu, suniti ili šijiti, sufije ili salafije, slažu u pogledu dva temeljnaizvora islama - Kurana i pripovjedne tradicije proroka Muhameda (sunet). »Iz tih je izvora raspoređen i izveden niz načelai praksi, koje čine srž islamskoga nauka, a oko kojih se slažu sve pravne tradicije i škole: šest stupova vjere (arkan al-iman), koji čine vjeru (al-aqida), i pet stupova islama (arkan al-islam), koji detaljno uređuju rituale (ibadat, obožavanje, ishrana itd.)«(Ramadan, 2012, 68).

Međutim, taj sveobuhvatni konsenzus oko osnovnih načela ukida se na drugoj razini izražavanja islamske civilizacije. Na toj se razini razvija mnoštvo divergencija zbog raznih interpretacija kuranskoga teksta i sekundarnih načela koja proizlaze iz prvih. Te divergencije dobivaju zatim ili oblik razlika između sunita i šijita, ili oblik razlika između brojnih legalističkih škola, te na taj način stvaraju ono što već poznajemo kao povijest islama.

Na drugoj razini unutar islamske civilizacije imamo hermeneutičko nesuglasje, a na trećoj razini imamo nesuglasje islama u odnosu na druge kulture, nesuglasje koje predstavlja srž onoga što Waardenburg naziva pučkim islamom. Ramadan piše: »Muslimani su živjeli u raznim vremenima i mjestima i suočavali su se s novim kulturama. Brojni elementi tih kultura integrirani su u islamske reference pozivanjem na legalno pravilo kojim se rukovodi u društvenim i kulturnim pitanjima: primarno je pravilo (u tim oblastima) dopuštanje (Ramadan, 2012, 68-69).

Svi suvremeni izazovi islama potječu iz nesuglasja na drugoj razini, koja se zatim impliciraju i u pitanjima treće razine. U tom kontekstu, Tariq Ramadan, profilirajući suvremeni islam, utvrđuje šest tendencija ili dominantnih struja u njegovu okrilju (Ramadan, 2004, 24-30).

1 Citati na hrvatskom jeziku iz engleskih izvornika prijevod su autora ovoga članka. 


\section{Dominantne struje suvremenoga islama}

\subsection{Skolastički tradicionalizam}

Prva je od tih struja, prema Ramadanu, skolastički tradicionalizam. Ta struja odnosi se na velike škole islamskoga prava, razvijene tijekom srednjovjekovlja, a koje se temeljena ideji hermeneutičkoga posredovanja između kuranskoga teksta i muslimanskih vjernika. Ramadan smatra da su šest njih najvažnije: Hanafi, Maliki, Shafi, Hanbali, Zaydi, Jafari. ${ }^{2}$

Interpretirajući različitim metodologijama islamsko pravo, te su škole stvorile uvjete za pojavljivanje pluralizma u tehničkoj provedbi islamskoga vjerskoga djelovanja unutar zajednice vjernika, gdje svaka od njih ima pretenzije na monopol nad islamskom ortopraksijom (pravilno prakticiranje vjere i obožavanja) i različito rješavanje legalnih problema. Fokusirane na tu dimenziju te škole, po Ramadanu, nemaju elaborirano stajalište ni sklonosti za izravno političko i društveno uključivanje u rasprave oko moderne ${ }^{3}$.

\subsection{Doslovni salafizam}

Druga je važna struja u suvremenom islamu doslovni salafizam. Na arapskom riječ salaf odnosi se na pretke, što u islamskom kontekstu znači da je riječ o prvim generacijama islama, generacijama koje su živjele u vrijeme proroka Muhameda. Suvremeni salafisti smatraju da je autentični, originalni islam, idealan način vjerskoga obožavanja i vjerske prakse, onaj koji su primjenjivale te generacije. Biti istinskim muslimanom znači ponašati se i vjerovati kao prvi muslimani (salafi). $\mathrm{Na}$ temelju toga doslovni salafisti, prema Ramadanu, odbacuju hermeneutičko

2 Prve četiri škole pripadaju suni islamu, a dvije posljednje shija islamu. Produbljeniju analizu prirode tih škola možemo naći u djelima jednoga od najpoznatijih proučavatelja islamskoga prava Wael B. Hallaqa (usp. Hallaq, 1997; Hallaq, 2009).

3 U suvremenoj filozofiji postoji velika rasprava o terminu moderna. U mnogim raspravama često se ne razjašnjavaju semantičke razlike između termina moderna i moderniziranje. Poznati autori, osobito oni koji pripadaju kontinentalnoj filozofiji, inzistiraju na ideji razlike između ta dva termina. Jedan od tih autora je njemački filozof Jürgen Habermas, koji u svojem slavnom djelu Filozofski diskurs moderne razrađuje tu distinkciju. Prema Habermasu moderniziranje se odnosi na »svežanj kumulativnih i uzajamno se jačajućih procesa: na stvaranje kapitala i mobiliziranje resursa; na razvoj proizvodnih snaga i povećavanje produktivnosti rada; na postavljanje centralnih političkih vlasti i na formiranje nacionalnih identiteta; na proširenje političkih prava sudjelovanja, urbanih životnih formi, formalnog školskog obrazovanja; na sekulariziranje vrijednosti i normi itd.«(Habermas, 1985, 10). Kad je riječ o terminu moderna, Habermas u spomenutom djelu smatra da diskurs o tom počinje s Hegelom, koji »koristi pojam moderne prije svega u historijskom kontekstu, kao pojam epohe: 'novo vrijeme' je 'moderno vrijeme'. To odgovara suvremenoj engleskoj i francuskoj jezičnoj uporabi: modern times odnosno temps modernes oko 1800. označavaju tri posljednja stoljeća. Otkriće 'novoga svijeta', kao i renesansa i reformacija — ta tri velika događaja oko 1500. godine čine epohalni prag između novovjekovlja i srednjovjekovlja (Habermas, 1985, 13).Također, moderniziranje i modernu ne treba pobrkati s terminom modernizam, koji je kolektivni izraz za trendove i struje umjetnosti i kulture koji se pojavljuju krajem 19. stoljeća i tijekom prve polovice 20. stoljeća. O modernizmu usp. Childs, 2000. Citati na hrvatskom jeziku iz njemačkoga izvornika Habermasova djela Filozofski diskurs moderne prijevod su Kristëa Shtufija. 
posredovanje pravnih škola kao nepotrebno i katkada i štetno. Oni zahtijevaju doslovno i izravno shvaćanje kuranskoga teksta i tradicije suneta, a time i generaliziranje vrijednosti normi koje su sadržane u Kuranu i sunetu. Putem te generalizacije doslovni salafisti apsolutiziraju te norme. Taj apsolutizam čini filozofsku osnovu netolerancije i vjerskoga fanatizma.

\subsection{Reformistički salafizam}

Blizak je toj struji i, kako ga Ramadan naziva, reformistički salafizam, kojemu je s doslovnim salafizmom zajednička idealizacija života prvih muslimana (salafa) te izravno čitanje i prihvaćanje kuranskih sadržaja, ali se od njega odvaja time što afirmira, suprotno apsolutnoj imitaciji doslovnih salafista, dimenziju koja se u islamskoj teologiji naziva ijtihād, koja podrazumijeva nezavisno promišljanje i kreativno nastojanje tijekom obnašanja vjerske prakse, koja je uglavnom vezana za primjenu prava. Ijtihād dolazi do izražaja u pravnim situacijama kada kuranski tekst ili proročki hadith ne pruža jasno rješenje za određeni zakonski slučaj. Taj se nedostatak nadomješćuje posredstvom analogijskoga promišljanja pravnika (Hallaq, 1997, 23).

\subsection{Doslovni politički salafizam}

Četvrta je važna struja suvremenoga islama, prema Ramadanu, doslovni politički salafizam. Ta je struja u svojoj biti radikalna i revolucionarna jer je njezin glavni cilj uništenje modernoga političkoga i društvenoga poretka, i stvaranje novoga društvenoga poretka utemeljenoga na društvenoj i vjerskoj praksi prvih muslimana iz vremena Proroka. Taj novi poredak treba biti poredak kalifata, gdje će osnovni i apsolutni zakon biti šerijat, putem kojega se uspostavlja Božje kraljevstvo na zemlji. Doslovni politički salafizam, u mnogom poznat i kao politički islam, u svojoj je biti anti-moderan, jer proces moderniziranja vidi kao proces degeneracije i udaljavanja od idealnosti života salafa. On je anti-zapadnjački, jer se Zapad smatra glavnim razlogom te degeneracije. On je anti-demokratski, jer je za njega suveren Bog, a ne narod. Reakcionaran je, jer ima za cilj vratiti unazad povijest čovječanstva u neki davni trenutak njezina vremenskoga tijeka. On je netolerantan, jer inzistiranjem na apsolutnoj vrijednosti početnoga islama sve druge oblike vjerovanja i obožavanja smatra pogrešnim i nedopuštenim. On je također manihejski, u smislu da dijeli svijet na dobre i loše, te apsolutan i konačan, jer pretendira posjedovati apsolutnu idefinitivnu istinu o svijetu i ljudskom životu, te da su obvezni širiti ju na cijelo čovječanstvo, makar i primjenom sile. Jasno je da su pokreti kao ISIS najvjerniji predstavnici doslovnoga političkoga salafizma. Kada se svijet čudi njihovoj hladnokrvnosti prilikom masakara, nema se u vidu da je ta hladnokrvnost u svojoj suštini hladnokrvnost nasilja u starom svijetu, gdje je nasilje bila svakodnevna i normalna praksa. ${ }^{4}$ Obezglaviti čovjeka

4 Enest Gellner piše da su agrarna društva, koja su u svojoj suštini poljoprivredna društva »osuđena živjeti nasiljem« i da je »mač snažniji od pluga«, što znači da ratnici imaju punu vlast nad proizvođačima (Gellner, 1988, 143-144). Gellnerova je ideja slična teoriji Herberta Spencera u djelu First Principles (1862.), koji veliku tranziciju iz srednjovjekovnoga razdoblja u novovjekovni 
u vrijeme kalifa Omara bila je sasvim uobičajena stvar. Dapače, ta uobičajenost postoji do javnih egzekucija sječenjem glava od strane jakobinaca u revolucionarnoj Francuskoj 1793. godine. Kao što piše Foucault u svojim djelima Discplina i kazna: Rođenje zatvora i Povijest seksualnosti: Volja za znanjem, humanizacija kazne kasni je fenomen, koji počinje tek u 19. stoljeću, kada vlast utemeljena na pravu suverena nad životom i smrću svojih podanika počinje gubiti teren suočena s novim oblicima vlasti, kao što su disciplinska vlast i biovlast, koje efektivnost vladavine povezuju s demonstracijom sile, nego s nadziranjem i administriranjem života ("biološka bogatstva nacije"). U kontekstu biovlasti »najviša funkcija vlasti nije ubijanje, nego investiranje u život« (Foucault, 1978, 191). Zato, indignacija koju danas pobuđuju javne egzekucije ISIS-a u stvari je indignacija biopolitičke savjesti modernih društava. Kalifat ISIS-a, piše Žižek (2014), u potpunosti odbacuje foucaultovsku koncepciju biovlasti.

\subsection{Liberalni ili racionalistički reformizam}

Jedna druga struja u suvremenom islamu, prema Ramadanu, je liberalni ili racionalistički reformizam. Ta struja inzistira na ideji da islam treba prilagoditi zapadnjački model moderniziranja, model koji se poziva na veliki proces sekularizacije, posredstvom kojega se razne sfere društvenoga života emancipiraju od kontrole vjerskih uglednika. Ta struja stremi tomu da u islamskom svijetu širi ideje i vrijednosti prosvjetiteljstva, a kao važan primjer u tom kontekstu smatra se kemalistički model, primijenjen u modernoj Turskoj pod vodstvom Kemala Ataturka, počevši od dvadesetih godina 20. stoljeća. Glavni se inspiratori te struje nalaze u zapadnom svijetu i njezin utjecaj, čini se, još je uvijek vrlo slab u samom arapskom svijetu. Turski kemalizam ne samo da se nije uspio proširiti izvan granica Turske, nego, čini se, on je danas pred izazovima i unutar nje same. Još je jedan primjer neuspjeh takozvanoga „arapskoga proljeća”, koje se u svojim početcima nadahnjivalo zapadnim modelom demokratskih revolucija, ali koje je zatim degeneriralo u povratak vojne diktature u Egiptu, kao prevencija stvaranja teokratskoga Egipta, i u građanski rat u Siriji, koji je zadobio razmjere međusektaškoga sukoba po starim linijama sukoba između sunita i šijita. Ono što je Slavoj Žižek (2011) nazvao „čudo Trga Tahrir” završilo je užasom masakara salafističkih militanata u poljima Mosula u ljeto 2014 godine.

Sada je već poznato da je moderniziranje u arapskom svijetu na lošem glasu, jer je nakon dekolonizacije moderniziranje postala sinonimom rađanja niza autoritarnih država, kvazisekularnih i korumpiranih, koje su, podržane od strane Zapada zauzetoga velikim ideološkim sukobom s komunističkim svijetom, dalje produbile svoj autoritarizam stvarajući tako anti-modernu i anti-zapadnu klimu, klimu koja je zatim postala plodno tlo za cvjetanje islamskoga radikalizma. Klasičan je primjer tomu Islamska revolucija u Iranu 1979. godine. Oštra reakcija na

svijet interpretira kao prelazak iz vojnoga društva, gdje su nasilje i sila determinirajući čimbenici društvenih odnosa i fenomena, u industrijsko društvo u kojem mirna proizvodnja gospodarskoga života određuje cjelokupnost društvenoga života (Spencer, 2009). 
tu revoluciju pridonijela je da se islamskomu militantizmu pridoda ranije nepoznata dimenzija: suicidalni džihad. ${ }^{5}$

\subsection{Sufizam}

Šesta je struja u suvremenom islamu koju ističe Ramadan sufizam, koji u povijesti islama ima vrlo dugu i bogatu tradiciju u pogledu raznolikosti pristupa. Za razliku od radikalnoga političkoga aktivizma salafizma, sufizam je usredotočen na prakticiranje mističnoga islama, što znači na individualno moralno samousavršavanje putem meditiranja i kontemplacije. Za sufije kuranski tekst nije poticaj za političko djelovanje, nego za mističku meditaciju, koja predstavlja jedini put za postizanje božanske spoznaje. Sufizam je neka vrsta individualističkoga islama, koji više aspirira moralnu savršenost pojedinca negoli kolektiviteta. ${ }^{6}$

\section{Koncept svetoga rata u abrahamskoj tradiciji i džihad}

\subsection{Metafizička konotacija}

Ako danas postoji nešto što islam čini zastrašujućim u očima preostaloga svijeta, to je bez dvojbe ideja džihada. Upravo je to ideja pomoću koje se danas samoafirmiraju razni radikalni pokreti u islamskom svijetu, i osnovno je pitanje u tom kontekstu u kojoj je mjeri ta samoafirmacija u skladu s konceptom svetoga rata koji je sadržan u svetim islamskim spisima.

Iako se na prvi pogled čini jasnim, taj je koncept u stvari u velikoj mjeri kompleksan, između ostaloga i zbog njegovih metafizičkih konotacija. Zamišljanje jedine apsolutističke i univerzalne religije predstavlja temelj na kojem se gradi i ideja svetoga rata. U tom kontekstu Bernard Lewis piše: »Ideja da postoji jedna i jedina istina za cijelo čovječanstvo, i da je zadaća onih koji je posjeduju prenošenje ostalima, začinje se dolaskom kršćanstva i pojavljuje se ponovo rađanjem islama. Obje su vjere začete na Srednjem istoku i skupile su vrlo široku zajedničku tradiciju, u koju su uključene židovske ideje o monoteizmu, proroštvu, božanskom otkrivenju i svetim spisima; filozofija i nauci Grčke; pravo i institucije upravljanja Rimljana te, vraćajući se nazad još dalje u vremenu, tradicije koje su preživjele iz još drevnijih civilizacija toga područja. Kršćanstvo i islam imali su zajedničku novu ideju, ranije nepoznatu, da su jedini u posjedu božanske istine $u$ njezinoj cijelosti« (Lewis, 1994, 16).

5 Poznati francuski proučavatelj islama Gilles Kepel (2008, 78-89) smatra da je suicidalni džihad (mučeništvo) kao sredstvo u borbi šijitskoga podrijetla te da se njegov začetak povezuje s danima islamske revolucije u Iranu. Umiješani u neravnopravan rat sa Irakom, koji su podržavale SAD, s ciljem odbrane svoje revolucije, ajatolasi su na čelu s Khomeinijem oživjeli stari mit mučeništva imama na čelu sa imamom Huseinom 680. godine za očuvanje vjere, potičući mlade Irance da učine isto za očuvanje islamske revolucije, dakle da ostvare mučeništvo samoubilačkim bombaškim napadima neprijateljskih redova. Tu je praksu kasnije usvojio Hezbolah u Libanonu, a zatim je ona prešla i među sunite.

6 Za uvid u sufizam usp. Geoffroy, 2010. 
Apsolutni epistemološki monizam kršćanstva i islama proizlazi direktno iz njihova monoteizma. Dakle, budući da postoji jedan jedini Bog, apsolutan i definitivan, treba postojati i jedna istina, apsolutna i definitivna, i budući da je taj Bog svemoguć i sveprisutan, i njegova istina treba biti svemoguća i sveprisutna. Sveti rat ima za cilj uspostavljanje silom podudaranje između ontološkoga prisustva Boga i njegova epistemološkoga prisustva u svijetu.

\subsection{Zapadna i islamska tradicija}

Američki učenjak James Turner Johnson konceptu svetoga rata posvetio je produbljeno istraživanje, $\mathrm{s}$ fokusom na kršćanstvo i islam. Ta istraživanja sažeo je u svojoj knjizi The Holy War Idea in the Western and Islamic Traditions (»Ideja svetoga rata u zapadnoj i islamskoj tradiciji «, 1997). Usprkos kompleksnosti kojom je protkana ta ideja, Johnson (1997, 36-38) smatra da iz analize povijesnih primjera u kojima je ona provedena možemo identificirati nekoliko značenja koje se tiču njezine biti. On identificira deset takvih, ali ovdje nije mjesto da ih sve elaboriramo.

U primarnom smislu, primordijalnom, sveti rat podrazumijeva rat koji se vodi Božjom zapovjedi. Primjere takvoga značenja, prema Johnsonu, možemo naći u tradiciji sve tri abrahamske religije, od biblijskih priča drevnoga Izraela, onih islamskoga džihada koji ima za cilj podčinjavanje cijeloga čovječanstva Božjoj zapovjedi, sve do vjerskih ratova engleskih puritanaca u vrijeme europske vjerske reformacije. U tom kontekstu čitamo o pojmu džihada u klasičnoj islamskoj misli: »izraz džihad bio je raširen u klasičnoj islamskoj misli, a koristio se za označavanje borbe, od božanstva odobrene, ratom ako se ukaže potreba, radi uspostavljanja islamske suverenosti, a time i širenje islamske vjere među nevjernicima $\ll$ (Hashmi, 2016, 584). ${ }^{7}$

To značenje vjerskoga rata proizlazi iz predodžbe Boga koji se ozbiljno uključuje u događaje povijesti i koji ih želi usmjeriti u skladu sa svojom voljom. Takva je predodžba suštinska u tradiciji abrahamskih religija. Najvažniji sveti događaji u toj tradiciji izražavaju takav koncept, od biblijskoga egzodusa židova iz Egipta, zatim rođenja, smrti i uskrsnuća Kristova, do krvavih bitaka Muhameda u poljima Arabije protiv politeista.

Ideja Boga koji intervenira tijekom povijesti, koji želi provesti svoju volju, bila je jedna od određujućih ideja zapadnoga političkoga i filozofskoga mišljenja u novovjekovnoj epohi, koja prema interpretaciji Karla Löwitha (1957) tijekom procesa sekularizacije nije učinila ništa drugo osim što je značenje njem. Heilsgeschichte (sveta kršćanska povijest spasenja) prevela na njem. Weltgeschichte (svjetska povijest). Najistaknutiji su primjeri te transformacije bez sumnje Hegel i Marx. Hegel je borce bitaka Heilsgeschichte pretvorio u ,agente svjetskoga uma”, a Marx je iste pretvorio u borce proletarijata, čija je misija uspostavljanje konačnoga moralnoga poretka u svijetu. $\mathrm{U}$ tom kontekstu danas vide sebe i islamski

7 Citati na hrvatskom jeziku iz engleskih izvornika prijevod su Vesne Borović.

8 Tu je sintagmu Herbert Marcuse upotrijebio u svojoj knjizi o Hegelovoj filozofiji povijesti (Marcuse, 1955, 232). 
džihadisti, za koje je univerzalni kalifat ekvivalent toga konačnoga poredka. Na temelju te ekvivalentnosti njemački filozof Peter Sloterdijk (2010, 220-221) u svojoj knjizi Rage and Time (»Bijes i vrijeme«) uviđa trostruku analogiju između povijesnoga komunizma i političkoga islama.

\subsection{Povijesni komunizam i politički islam}

Prvo, jednako kao povijesni komunizam jučer, politički islam danas manifestira vrlo dinamično i inspirativno misionarstvo, s univerzalnim pretenzijama, koji je adresiran s onu stranu svih ljudskih razlika, zavodi marginalizirane, neodlučne i bijesne, sebe predstavlja kao spiritualnoga i materijalnoga odvjetnika siromašnih, pridobivajući tako simpatije i srca u svijetu bez srca.

Drugo, mišljenja je Sloterdijk, zavodljivost političkoga islama izvire iz toga što je on u stanju ponuditi svojim sljedbenicima veličanstven teatralni svjetonazor, jasan i agresivan, oslonjen na jasnoj razlici između prijatelja i neprijatelja, nepogrešivoj misiji za pobjedu i konačnoj utopijskoj viziji usavršavanja: obnovi globalnoga emirata, koji treba poslužiti kao temelj za islamski milenarizam (Vječnu Vladavinu Islama na zemlji). Prema Sloterdijku, takvu milenijalističku viziju i takav teatralan i agresivan svjetonazor ranije je samo komunizam bio u stanju ponuditi svojim sljedbenicima i čovječanstvu. Međutim, slabost komunizma i iscrpljivanje njegove energije poteklo je od »utopijske budućnosti koja nikako nije dolazila«, a kod političkoga islama glavnu slabost Sloterdijk vidi u njegovoj orijentaciji nazad u povijest i nemoć njegovih lidera da formuliraju kreativnu viziju za budućnost. Ostvarivanje njihova sna za restauriranje velikoga neo-srednjovjekovnoga islamskoga imperija bez ikakve je realne osnove (Sloterdijk, 2010, 225).

Treća je dimenzija analogije koju zapaža Sloterdijk između povijesnoga komunizma i političkoga islama ta da je dramatični porast toga posljednjega rezultat demografske dinamike u oblasti njegova regrutiranja, oblast koja obuhvaća zemlje s demografskim bumom stanovništva, što diktira dominaciju mladoga uzrasta unutar njih. »Jednako kao totalitarni pokreti 20. stoljeća,on je pokret omladine ili, specifičnije kazano, pokret mladih ljudi «(Sloterdijk, 2010, 221). ${ }^{9}$ To su obično mladi koji su, u raznim zonama svijeta, pretrpjeli najrazličitije oblike marginalizacije kao posljedica dramatičnih procesa globalizacije.

Štoviše, može se reći da analogija između povijesnoga komunizma i političkoga islama ne biva iscrpljena tim trima elementima koje analizira Sloterdijk. Kao što je poznato, jedan od važnih izvora boljševizma i Ruske revolucije 1917. godine i tradicija je ruskoga političkoga mišljenja 19. stoljeća, s njegovim strujama anarhizma, populizma, revolucionarnoga nihilizma i terorizma. Lenjinizam je u svojoj biti splet zapadnoga marksizma s elementima tih struja. Među figurama

9 Sloterdijkova teza podsjeća nas na jednu od najdubljih analiza fašizma, koju je dao George L. Mosse. On je u svojim brojnim spisima o fašizmu iznio ideju da je fašizam započeo kao pokret mladih, pokret koji je mobilizirao mlade pobunjene protiv društva, roditelja i škole, i koji su, žedni novoga smisla zajednice, potaknuti na militaristički aktivizam i ideale povezane s njime (Mosse, 2010, 70-71). 
koje obilježavaju rasprave i polemike među tim strujama nailazimo i na Sergeya Gennadiyevicha Nechayeva, koji se danas pamti po dvjema stvarima: njegove vizije komunizma, kritizirane od strane Marxa (Marx et al., 2001, 88),kao vizije komunizma baraka, i po jednom tekstu napisanom u obliku vjerskoga žanra kateheze, pod naslovom Katekizam Revolucionara (1869). U tom tekstu Nechayev iznosi značajke i načela koji trebaju voditi mišljenje i djelovanje revolucionara. Revolucionar, kaže Nechayev, nema osobnih interesa niti se bavi pitanjima biznisa, nema ni emocije ni imovine ni imena. Kod njega je sve reducirano na jedno jedino mišljenje i strast: revoluciju. Temeljni je uvjet za revolucionara da on ukine sve veze s postojećim društvenim poretkom i civiliziranim svijetom, njegovim zakonima, običajima, moralnim normama i prihvaćenim konvencijama. On treba nastupiti kao nepokolebljivi neprijatelj svega toga. Revolucionar prezire moral javnoga mnijenja, za njega je moralno sve što pomaže revoluciju i nemoralno sve što je sprječava. Revolucionar treba biti nemilosrdan i treba naučiti provoditi torturu. Nasilje za njega nije prepreka, nego prednost. Bivajući tiraninom prema samom sebi, on treba biti tiranin i prema drugima. Treba eliminirati sve osjećaje sućuti i žaljenja te se danju i noću posvetiti samo nemilosrdnomu uništenju postojećega poretka. On nije revolucionar ako ima i najmanju simpatiju za taj poredak. On poznaje samo jednu vrstu prijateljstva i bratstva: bratstvo revolucionarnih drugova. On ne poznaje moralne limite u svojoj borbi za veliki cilj. Za njegovo postizanje opravdana su sva sredstva i putevi. Njegova je etika ono što Weber naziva "etikom definitivnih ciljeva". U toj točki realni komunizam i politički islam također se susreću. Taj se posljednji, mišljenja je Sloterdijk, pothranjuje upravo vakuumom koji je za sobom ostavio pad realnoga komunizma, koji Sloterdijk naziva "postkomunističkom konstelacijom”. Politički islam je parazit te konstelacije (Sloterdijk, 2010, 218).

Iz svega je toga jasno da se kod Nechayeva figura revolucionara i terorista stapaju u jedno, i da je psihologija njegova revolucionara identična psihologiji današnjih džihadista ISIS-a i Al Qaide. ${ }^{10} \mathrm{U}$ tom smislu nedostatak milosrđa i ekstremna brutalnost koju oni demonstriraju danas u svojem nasilju nema podrijetlo samo u njihovoj strasti za imitacijom salafista ranoga srednjega vijeka, nego i u strasti modernih revolucionara, čiji račun dostiže milijune žrtava (usp. Courtois et al., 1999). Katekizam Nechayeva je i katekizam ISIS-a.

\subsection{Militaristički i moralno-duhovni pojam džihada}

Vratimo se sada Johnsonovoj analizi značenja koje asociraju na ideju svetoga rata. Po njemu, mi možemo govoriti o situaciji svetoga rata kada on biva autori-

10 Jedan od najboljih poznavalaca ruskoga političkoga mišljenja Nikolaj Berdyaev u svojem je djelu Ruska ideja, analizirajući Nechayevljev katekizam, ustanovio u njemu duh fanatizma i terorizma. Nechayeva je nazvao fanatikom i zelotom (Berdyaev, 1948, 117). Zelotima su nazivani pripadnici židovske pobune protiv rimske vladavine u 1. stoljeću, nekoliko desetljeća nakon Kristove smrti. Berdyaev koristi taj naziv da bi odredio terorističku dimenziju u tekstu Nechayeva, jer su zeloti poznati u povijesti kao prvi pokret koji je koristio metode nasilja koje danas poznajemo kao terorističke metode, primjerice nasilje prema civilima i brutalna egzekucija onih koji odbijaju podržati pokret (Chaliand i Blin, 2007, 55-78). 
ziran od strane autoriteta koji ima pravo predstavljati Boga ili govoriti u njegovo ime. Klasični su primjeri u tom slučaju papinske autorizacije za križarske ratove tijekom srednjovjekovlja, koje su u potpunosti izgubile svoju snagu početkom novovjekovlja tijekom velikoga procesa sekularizacije. Takvi primjeri ne nedostaju ni u islamskoj tradiciji, kako u šijitskoj, tako i sunitskoj. Čak, u islamu je autorizacija za sveti rat još izravnija, imajući u vidu to da tradicija utemeljena od strane Muhameda nije pravila jasnu razliku i ne postavlja jasne granice odvajanja između vjerskoga i političkoga autoriteta. Sama proročka karijera Muhamedova primjer je po tom aspektu: on je istovremeno bio duhovni vođa, vojni zapovjednik i politički upravitelj. Takvu situaciju Weber naziva cezaro-papizmom, što znači jedinstvo političke i duhovne vlasti. Cezaro-papizam je u osnovi islamske koncepcije o vjerskom ratu (jihad). Sam termin jihad u doslovnom prijevodu ima značenje nastojanja, zalaganja i rata, značenje koje u vjerskom kontekstu dobiva svojstvo nastojanja i rata na Božjem putu (Johnson, 1997, 37).

Brojni su proučavatelji nastojali da se islamski koncept džihada shvati u široj perspektivi od njegova vojnoga značenja, i u tom pravcu je provedena klasifikacija džihada na Božjem putu u četiri vrste: džihad srca (vjere), čija se suština odnosi na nastojanje čovjeka za jačanje svoje vjere; džihad jezika (ispravno govoriti), koji podrazumijeva nastojanje za uspostavljanje diskurzivne dominacije božanstvene riječi unutar sebe i društvenoga okruženja; džihad ruku (činjenje dobrih djela), čiji je kriterij dobročinstvo prema božanskim naredbama; i džihad mača (sveti rat), koji podrazumijeva uporabu sile u funkciji odbrane ili širenja islama (Johnson, 1997, 62).

U pogledu važnosti tih oblika džihada, proučavatelji se često pozivaju na izreku proroka Muhameda, koji je jednom prilikom ustvrdio razliku između džihada mača kao „maloga džihada” i duhovnoga džihada kao „velikoga džihada” (Johnson, 1997, 62; usp. Newby, 2002, 115-116; Hashmi, 2016). Drugomu je pridan smisao nastojanja za potpuno očišćenje samoga sebe radi stjecanja dostojnosti Božje milosti. To nastojanje, u kontekstu abrahamskih religija koje se temelje na etičkom konceptu Boga, ima smisao moralnoga samousavršavanja, koje unutar islama najviše dolazi do izražaja u sufijskim strujama.

Takve diferencijacije dospjele su do konstatacije da islamski termin džihad više treba uzimati u moralno-spiritualnom smislu, nego u militarističkom. Međutim Bernard Lewis, jedan od najvećih proučavatelja islama, brani suprotno stajalište. Po njemu, moralna i spiritualna interpretacija koncepta džihad razrađena je uglavnom od strane šijitskih teologa klasične epohe, a zatim najviše od modernizatora i reformatora 19. i20. stoljeća, koji su nastojali prenijeti prosvjetiteljske tendencije unutar islamskoga svijeta, međutim golema većina klasičnih teologa, pravnika i tradicionalista koncept džihada shvaćaju upravo u njegovu militarističkom značenju. Lewis kaže: »Sve veličanstvene kolekcije hadita sadrže sekciju posvećenu džihadu, u kojima dominira militarističko značenje. Isto važi i za naputke zakona šerijata«(Lewis, 1988, 72).Sličnoga su mišljenja Cox i Marks kad tvrde: »Džihad se može protumačiti duhovno kao borba za vođenjem svetoga života; međutim uporaba termina se može proširiti na obvezu — nametnutu od Alaha svim muslimanima — da neprekidno teže za obraćenjem ili podjar- 
mljivanjem ne-muslimana. Džihad u potonjem smislu nije ograničen vremenski ni prostorno te će trajati sve dok čitav svijet ne prihvati islam ili se ne podvrgne islamskoj državi« (Cox i Marks, 2002, 79). S tim stavom u vezi Bonney kaže: »Ideja o islamskoj doktrini permanentnoga rata može se svidjeti protivnicima islama, i čini se da je priznata od strane islamskih teoretičara, no u stvari je pogrešna (Bonney, 2004, 4). Mi mislimo da Bonney tu nameće nepravedno misao da ako se ukazuje na činjenice, onda će se time neko automatski učiniti protivnikom islama. Međutim, mislimo da je to logička greška, jer se neće pravilno zaključiti iz ukazivanja na činjenice na predikat protivljenja ili ne jednoga svjetonazora, jedene religije ili jedne ideologije.

\subsection{Povijesni kontekst kuranske objave}

Izgleda da se bitan razlog koji može pomoći u tom smjeru povezuje s povijesnom činjenicom da se kuranska objava, u svojem većem dijelu, dogodila u vrijeme kada su Muhamed i njegovi sljedbenici bili uključeni u otvoreni oružani sukob s njegovim protivnicima. To je utjecalo na to darat bude toliko puno prisutan u kuranskim surama, i da preko njezinih dnevnih emergencija utječe i na semantiku mnogih od tih sura. U suri At-Tawba, koja pripada medinskomu razdoblju proroštva, stihovi 38 i 39 jasno izražavaju te emegencije. U njima se kaže: »O vjernici, zašto ste neki oklijevali kada vam je bilo rečeno: 'Krenite u borbu na Allahovu putu!', kao da ste za zemlju prikovani? Zar vam je draži život na ovom svijetu od onoga svijeta? A uživanje na ovome svijetu, prema onome na onom svijetu, nije ništa. Ako ne budete u boj išli, On će vas na nesnosne muke staviti i drugim će vas narodom zamijeniti [...].«

Tu nema dvojbe i izbora između rata i života, nego dvojbe i izbora između odlaska u rat i smrti kao kazne zbog njegova izbjegavanja. Bijeg od rata izaziva nesuzdrživ gnjev Boga. Ti stihovi nisu jedini. Izgleda da je na temelju toga Max Weber došao do zaključka da je islam više religija ratnika negoli drugih društvenih grupacija. Njegov etos je etos ratnika. Weber piše da u islamu »tip idealne osobe nije intelektualac, nego ratnik« (Weber, 1978, 626). Šehid (ratnik ubijen na putu Alaha) u mnogim se kuranskim stihovima vrednuje kao najdraži čovjek Boga, i ta je vrsta militarizma utjecala i na zamišljanje onostranoga svijeta u islamu. Weber piše: »U islamu je onostrani svijet predočen kao čulni raj za ratnike « (Weber, 1978, 625). Ta nam Weberova stajališta omogućavaju da shvatimo u velikoj mjeri današnji entuzijazam militanata islamskih pokreta ISIS ili Al Nusra i njihove ozbiljne pretenzije da je njihov islam najautentičniji i originalni oblik islama. U izvjesnom smislu, weberianska analiza daje im za pravo.

Ta militaristička dimenzija početnoga islama koju evidentira Weber, kao i agresivan stav kuranskoga teksta prema drugim oblicima vjerskoga obožavanja, često se odbacuje pozivanjem na druge reference koje se nalaze unutar toga teksta, a koje izgleda da nam govore o uglavnom miroljubivom islamu. Jedna od njih je sura El-Kafirun, kratka sura gdje nalazimo ono što bismo mogli nazvati "stihom vjerske tolerancije”. Stih 6 kaže: »Vama — vaša vjera, a meni — moja!«. Kontekst toga stiha govori o stavu kojega se Muhamed treba držati prema vjer- 
nicima, i taj je stav vrlo tolerantan. Od njega se traži da drži svoju vjeru i da se ne bavi nevjernicima koji imaju svoju vjeru. Stav dostojan za uvrštavanje u osnovne liberalne traktate o vjerskoj toleranciji. Ali, liberalizam te sure, jasno je, u otvorenoj je kontradikciji s ostalim surama, gdje se naređuje progon nevjernika.

Kako se može objasniti ta kontradikcija unutar Kurana? Dobro polazište u tom smjeru nalazimo kod Webera, koji, kada govori o ranom islamu, smatra da se karakter islama mijenjao i tijekom samoga njegova proročkoga vremena. To znači da drugačiji karakter ima islam objavljen u prvom periodu u Meki, a drugačiji islam objavljen u periodu Medine. Islam u Meki, prema Weberu (1978), ima uglavnom eshatološki karakter. Njegova je priroda dominirana sklonošću za povlačenjem iz ovoga svijeta, a po odlasku Muhameda u Medinu, on se pretvara u ratničku religiju, s jasnim arapskim karakterom (Weber, 1978, 623-624). To je moglo utjecati na to da sure iz Meke budu tolerantnije te da se više fokusiraju na pitanja onostranoga svijeta, a progon nevjernika stvar je ostavljena Bogu. Objašnjenju se može pridodati i kontekstualno političko čitanje: u Meki Muhamed je praktički nemoćan da se silom suprotstavi politeistima koji ju realno imaju pod kontrolom. Jedini način preživljavanja tek osnovane religije jest putem jezika suživota s drugim vjerama. Po odlasku u Medinu stanje se mijenja. Tu Muhamed osniva prvu zajednicu muslimana, dobro ju naoružava i šalje u rat s politeistima. Ratno stanje zahtijeva drugačija stajališta: više nema mjesta toleranciji; protivnike treba uništiti; njihovo toleriranje je samouništavajuće. U tom se kontekstu pravo progona nevjernika udvostručuje: božanstvenomu progonu onostranoga svijeta pridodaje se i ljudski progon na ovom svijetu, a sam Muhamed, prema Weberu, doživljava transformaciju od pijetističkoga vođe u gradu Meki u političko-vojnoga vladara u Medini, tipa podestà (Weber, 1978, 473).

\subsection{Epistemološki i moralni apsolutizam abrahamskih religija}

Još jedno značenje koje asocira s konceptom svetoga rata odnosi se na stanje $\mathrm{u}$ kojem sveti rat podrazumijeva rat koji ima za cilj afirmaciju pravedne religije ili uspostavljanje društvenoga poretka na temelju božanskoga autoriteta (Johnson, 1997, 38). U sve se tri abrahamske religije to značenje svetoga rata manifestira naširoko. Mojsije se popeo na goru kako bi primio božanski dekalog, koji je poslužio kao temelj nove zajednice židova, nakon izlaska iz društvenoga i političkoga poretka faraonskoga Egipta. Krist dolazi da bi osnovao kraljevstvo Božje na zemlji, a car Konstantin ${ }^{11}$ i papa Urban II. ${ }^{12}$ preuzimaju na sebe da to ostvare mačem. U Kuranu se muslimanima kaže da se trebaju boriti do dana kada cijela

11 Konstantin Veliki u povijesti je poznat kao prvi rimski car koji je Milanskim ediktom 313. godine obustavio progon kršćana, dopustivši slobodno prakticiranje kršćanstva, a zatim i započeo proces pretvorbe u glavnu religiju rimskoga svijeta. Car Teodozije proglasio je 380. godine Solunskim ediktom kršćanstvo službenom religijom u Rimskom Carstvu.

12 Papa Urban II. prvi je papa koji je 1095. godine pokrenuo prvi zapadni križarski rat protiv muslimanske vladavine na Srednjem istoku. U narednim desetljećima pape u Rimu pokrenuli su niz drugih križarskih ratova, koji su bili vođeni idejom oslobađanja svetoga Kristova groba u Jeruzalemu. Pape su imale pravo pokretanja križarskoga rata i unutar samoga kršćanstva, kada je 
Zemljina površina bude pod vlašću Božje riječi. Neće biti mira na Zemlji dok se ona ne bude utjelovila. Tu je i podrijetlo islamskoga koncepta bipolarne podjele svijeta na Dar al-Islam (kuća Islama) i Dar al-Harb (kuća rata). Gdje ne vlada islam, tamo je ratno stanje. Tu koncepciju danas nalazimo u ideološkim temeljima radikalnih džihadističkih pokreta kao što su ISIS i Al Nusra.

To značenje svetoga rata vezano je na ono što smo gore kazali o epistemološkom i moralnom apsolutizmu abrahamskih religija, posebno kršćanstva i islama. Putem toga apsolutizma sveti ratovi postaju dio velikih militarističkih pokreta, konačni cilj kojih je definitivno rješenje političkih i moralnih problema ljudskoga poretka. Prosvjetiteljstvo, iako oslobađa društvo od vlasti i vjerskih autoriteta, ne uspijeva se osloboditi i od milenijalističke strasti definitivnih rješenja, i iz toga oživljavaju neke od velikih ideologija novovjekovlja, kao što su komunizam i fašizam, ali i druge sekularne filozofije koje vjeruju da je već pronađen put prečicom za stizanje do konačne istine o svemu.

Po samoj svojoj prirodi milenijalistički pokreti zahtijevaju apsolutnu poslušnost i vjeru, a da bi to postignuli, nije dovoljan samo racionalni argument, nego je potrebna spremnost za nasilje protiv onih koji stoje ispred velikoga milenijalističkoga marša. Upravo s tim aspektom se povezuje još jedno značenje na koje nailazimo u koncepciji svetoga rata, a u kojoj se taj rat pojavljuje kao rat za osnaženje (afirmiranje) religije i osudu devijacije (Johnson, 1997, 38). U starozavjetnoj biblijskoj knjizi Levitski zakonik nalazimo scene gdje Mojsije uz blagoslov Boga naređuje kamenovanje prijestupnika uspostavljenih načela na Sinaju (Lev 20,27; 24,14-15.23). S druge strane, povijest kršćanstva, od polemika svetoga Augustina s donatistima ${ }^{13}$ pa do izopćenja Luthera od strane pape, puna je činova nasilja protiv onih koji su smatrani prijestupnicima, nevjernicima ili idolopoklonicima. U tom kontekstu, najmračnija je dimenzija bez sumnje crkvena inkvizicija protiv heretika tijekom srednjega vijeka.

$\mathrm{S}$ druge strane, unutar islama bijes protiv tih kategorija isto je toliko radikalan i kuranski je tekst vrlo eksplicitan u tom smjeru. On zahtijeva od muslimana da se bore protiv idolopoklonika i nevjernika do trenutka kada oni bivaju pobijeđeni i vjera u Alaha uspostavi svoju vladavinu. ${ }^{14}$ Idolopoklonstvo je unutar islama po-

bila riječ o nekom vjerskom pokretu koji je bio u suprotnosti sa službenom doktrinom Katoličke crkve. Takav je bio križarski rat protiv katara u 13. stoljeću.

13 Donatizam je hereza kartaškoga biskupa Donata u Africi (umro oko 355.) i njegovih sljedbenika, koja je naučavala da vrijednost sakramenata ovisi od duhovne čistoće klera.

14 U suri El-Bekare, najdužoj kuranskoj suri objavljenoj u Medini, nalazi se stih u kojem se nevjerovanje, u starom stilu, kriminalizira, čak do toga stupnja da se njegova kriminalnost smatra još težom od ubojstva. Stih glasi: »Nevjerovanje je teže od ubijanja « (naš je prijevod na temelju albanskoga izdanja prevoditelja Hasana I. Nahija). Uvršten je u cjelinu stihova 190-191 sure ElBekare, u kojoj se od muslimana zahtijeva da gone i ubijaju sve one koji se suprotstave Alahovu putu. Kriminalizacija nevjerovanja nije specifičnost samo u Kuranu ili pak u drugim biblijskim tekstovima. I u Platonovoj knjizi Zakoni, napisanoj skoro tisuću godina prije Kurana, nalazimo manje-više isto, osudu ateista na smrt, jer je ateizam za Platona bolest duše. Oni koji kritiziraju Platona za totalitarni karakter njegove filozofske misli, među kojima je najpoznatiji Karl Popper, između ostaloga pozivaju se na odlomke 908 i 909 dijaloga Zakoni, gdje Platon opisuje način kažnjavanja nevjernika i gdje se ateizam određuje kao bolest uma. U istom odlomku Platon govori 
vezano s važnim konceptom iz vremena njegovih začetaka, s konceptom džahilije. Taj se koncept odnosi na politeističku zabludu predislamske Arabije, što je ekvivalentno nepriznavanju Boga. Bivajući istovremeno i gnoseološki i moralni koncept, džahilija ima u nekom smislu i unutrašnje sokratske konotacije, jer implicira ideju da neznanje (nepoznavanje istinskoga Boga) vodi u loše i opake postupke (obožavanje lažnih božanstava). Sokrat je govorio manje-više isto, tj. da je neznanje izvor zla. Kasnije je Platon u svojoj alegoriji spilje život u neznanju opisivao kao bijedan život robova. „Nedužnost” te stare predodžbe islama u naše je vrijeme poništena od strane ideologa struja islamskoga radikalizma, koji ga izvlače iz uskoga povijesnoga konteksta i pridaju mu univerzalnu vrijednost u uvjetima suvremenoga društva. Jedan je od njih ideolog Muslimanskoga Bratstva Sayyid Qutb (Khatab, 2006, 10-43), koji je džahiliji posvetio središnje mjesto u svojim djelima (Cory, 2009). Za Qutba suvremeni ekvivalent predislamske džahilije zapadna je moderna sa svim svojim dimenzijama, sekularizmom, demokracijom, materijalizmom, senzualizmom, pragmatizmom, dopuštenim ateizmom itd. Sve su to oblici idolopoklonstva, i prvenstveni je cilj džihada njihovo uništenje. Qutb ide dalje uključujući unutar svijeta suvremene džahilije i kršćane i židove, jer po njemu oni zaslužuju tako nešto samim time što su prihvatili nevjerničke uvjete i načela moderne. To nije bilo predviđeno u klasičnom poimanju džahilije, gdje su se kršćani i židovi razlikovali od politeističkih idolopoklonika (Buruma i Margalit, 2004, 107). Na taj način Qutb i njegovi sljedbenici razvijaju teorije neslaganja između moderne i islama, a u istom smjeru ide i druga radikalna struja vahabizam, koji od svoje doktrine apsolutnoga monoteizma derivira nihilistički stav prema materijalističkim vrijednostima moderne (Waardenburg, 2002, 232-233). Na takav stav nailazimo danas u srcu militantne strasti pokreta kao što su ISIS i Al Qaida.

\section{Kuran između salafističke i hegelijanske interpretacije}

Kuran se može interpretirati na dva načina: salafistički i hegelijanski.

\subsection{Salafistička interpretacija Kurana}

Salafistička interpretacija tretira Kuran kao božanski tekst, unutar kojega je sve savršeno, i kao takav ima apsolutnu univerzalnu vrijednost. To znači da ono što je tamo rečeno jest i treba biti važeće za sva vremena, kontekste i situacije. Ako se kaže da idolopoklonike treba ubiti, onda to treba vrijediti jednako 632. godine i u 2014. godini. U salafističkom čitanju nije kontekst taj koji daje smisao kuranskomu tekstu, nego suprotno, kontekst se treba uobličiti u cjelini prema tom tekstu. Logika je takvoga stava jednostavna: apsolutni Bog ne može stvarati drugačiji tekst osim teksta koji ima apsolutnu vrijednost za sve situacije i okolnosti, u vremenu i prostoru. Kada takvu logiku ostavljamo na razini metafizičke 
špekulacije, opasnost biva limitirana samo na proizvodnji, kako ih je Kant nazivao, „transcendentalnih iluzija čistoga uma”, a koje je potonja analitička filozofija s Rudolfom Carnapom identificirala kao »iluzije proizvedene zloporabom jezika«. Međutim, ako odlučimo takvu vrstu apsolutizma pretvoriti u politički program i socijalni recept za način organiziranja društva, onda metafizički dogmatizam dobiva oblik vjerskoga i političkoga fanatizma. To se objašnjava time da se fanatizam temelji na stvorenom samouvjerenju od strane jedne skupine da je ona doživjela otkrivenje apsolutnoga. To samouvjerenje vodi tu skupinu prema manihejskoj viziji svijeta, viziji globalne podjele između dobra i zla, koja zatim neminovno zahtijeva sveti rat protiv zla. Sve je to u biti radikalnih pokreta kao što su ISIS i Al Nusra. Pravdanje njihova nasilja putem kuranskih sura moguće je samo ako se te sure čitaju po salafističkom modelu.

\subsection{Hegelijanska interpretacija Kurana}

Alternativa je tomu hegelijansko čitanje, čije je metodološko načelo da je svaki tekst izraz duha svojega vremena. To znači da svaki tekst govori i izražava probleme vremena u kojem je napisan, i nerazumno je pomišljati da on može transcendirati svoje vrijeme. ${ }^{15}$ Svaki pojedinac, piše Hegel, u svakom slučaju dijete je svojega vremena i ne može preskočiti njegova ograničenja. To vrijedi i za proroka Muhameda i njegovo vjersko iskustvo kodificirano u tekstu Kurana. Njegove brige u stvari su duhovne i političke zabrinutosti koje dominiraju Srednjim istokom u ranom srednjovjekovlju, i njegovi uspjesi u vezi su s time što je on djelovao u skladu sa zahtjevima glavnih smjerova svojega vremena, među kojima je glavna bila širenje monoteističkoga oblika vjerskoga uvjerenja. ${ }^{16}$

Za razliku od salafističkoga čitanja, hegelijansko čitanje tekst podvrgava kontekstu, i to ima za posljedicu negiranje pretenzija teksta na epistemološki apsolutizam (Kuran kao potpuna i definitivna istina), moralni univerzalizam (šerijat kao univerzalni moralni kod) i politički imperijalizam (islamski kalifat kao konačni svjetski politički poredak). U zapadnom svijetu to podčinjavanje teksta kontekstu proizvelo je historicističko-prosvjetiteljsku kritiku svetih biblijskih tekstova, ${ }^{17}$ koja je skupa s ostalim dimenzijama prosvjetiteljstva, nakon dugoga povijesnoga procesa, uspjela agresivno srednjovjekovno kršćanstvo pretvoriti u tolerantno kršćanstvo modernoga doba. U tom smislu može se reći da je Friedrich Meinecke u pravu kada historicizam naziva »jednom od najvećih intelektualnih revolucija

15 To se načelo može izvesti iz predgovora Hegelova djela Elementi filozofije prava. U tom predgovoru Hegel iznosi svoje gledište da je filozofska refleksija u svojoj biti samo retrospektivna refleksija. To načelo može se izvesti i iz koncepta o povijesti filozofije, koji Hegel razvija u svojem djelu Predavanja o povijesti filozofije. U njemu kritizira pretenzije raznih filozofija da iznose punu istinu o realnosti te iznosi ideju da istinska vrijednost svake filozofije leži u činjenici što ona predstavlja samo trenutak (dio) u rasvjetljavanju istine.

16 Najozbiljnije povijesne studije govore da su se tendencija ka monoteizmu i proces opadanja politeizma pojavili među arapskim plemenima nekoliko desetljeća prije vjerskoga pokreta Muhameda (usp. Waardenburg, 2002, 24-44).

17 Ta tradicija započinje Spinozinim spisima i doživljava buran razvoj u francuskom prosvjetiteljstvu i humanističkoj filozofiji lijevih hegelijanaca, kao što su Strauss, Bauer i Feuerbach. 
koju je doživjelo zapadno mišljenje« (Beiser, 2011, 1). Značenje termina historicizam kod Meineckea razlikuje se od značenja koje mu pridaje Karl Popper kao modernoga ekvivalenta fatalističke metafizike. Kod Meineckea historicizam se shvaća kao metoda ili gledište po kojoj sve vrijednosti, ideje i ljudske prakse proizvod su određenih povijesnih konteksta, i mogu se razumjeti i valorizirati samo posredstvom i unutar njih. U tom je smislu historicizam anti-apsolutističan i anti-esencijalističan.

\section{Kontekstualiziranje Kurana u povijesti}

Vraćajući se arapskomu svijetu, može se reći da će tomu svijetu, kako izgleda, biti teško pronaći mir ako ne doživi tu intelektualnu revoluciju u svojem kulturnom arealu. Taj doživljaj prvenstveno podrazumijeva kontekstualiziranje Kurana u povijesti, odakle se može derivirati njegova istinska vrijednost kao važnoga dokumenta ljudske civilizacije, ali ne i kao alfa i omega ove civilizacije. Kontekstualizacija ne podrazumijeva reduciranje Kurana samo na njegovu muzejsku vrijednost, nego otvaranje mogućnosti za njegovo selektivno čitanje u funkciji koegzistencije među kulturama u našem svijetu, koji je već dobio sve značajke onoga što je McLuhan nazivao „globalno selo”. ${ }^{18}$ Svlačenje Kurana od epistemološkoga, moralnoga i političkoga apsolutizma, koji smješta Arape muslimane na najvišem vrhu svjetske povijesti, predstavlja mentalni uvjet da se arapski svijet oslobodi od „kulture poniženja”, ${ }^{19}$ koja je prema Dominique Moïsi zahvatila ovaj svijet, i kao posljedica toga unutar nje je stvorena masovna psihologija osvete, koja se zatim utjelovila u takvim pokretima i skupinama kakve su Al Qaida i ISIS. Oslobađanje od kulture poniženja istovremeno je i oslobađanje od komplotističke interpretacije povijesti, ${ }^{20}$ koja, jednako kao Brana Mosula koja osigurava energiju dolini Mesopotamije, daje energiju za militantne strasti tih pokreta.

18 Vrijedi istaknuti da islamska teološka kultura nije sasvim izdvojena od unutrašnjih reformatorskih tendencija. U sklopu islamskih pravnih škola je i hanefitska škola, koja u svojoj biti sadržava načelo da se islamski zakon mora prilagoditi novim okolnostima, tj. treba se kretati usporedno s mijenama vremena, jer novi fenomeni i nove činjenice zahtijevaju nove odluke i rješenja (usp. Weeramantry, 1988, 50).

19 U svojem eseju o „geopolitici emocija” francuski politolog Dominique Moïsi piše da osjećaj poniženja dominira kada razlika između idealizirane i slavne prošlosti i razočaravajuće sadašnjosti postane vrlo velika. Taj je osjećaj u arapskom svijetu pretvoren u kulturu poniženja, koja se hrani kontrastom između zamišljanja slavne prošlosti (od Muhamedova trijumfa do pada islamskoga Kalifata u 13. stoljeću), i kasnijega stanja u arapskom svijetu, koje obuhvaća niz uzastopnih podčinjavanja, kao što su osmansko podčinjavanje, podčinjavanje od strane zapadnih imperijalističkih sila, ponižavajući poraz u konfliktu s Izraelom, podčinjavanje od strane autoritarnih i korumpiranih režima (usp. Moïsi, 2010, 25 i 94-139).

20 Politički teoretičar frankfurtske škole Franz Neumann (1988, 125-155) smatra da se komplotistička interpretacija povijesti javlja u situacijama velikih socijalnih kriza, kada skupine koje gube vlast ili dožive pad, nesposobne da racionalno shvate povijesni proces koji je prouzročio njihov pad, sklone su teorijama komplota, gdje se neosobni uzročni čimbenici pada zamjenjuju personificiranim krivcima za koje se vjeruje da su planirali i organizirali njihov pad. Takve teorije komplota iskorištavaju demagozi, koji proizvodnjom masovnoga straha uspijevaju mobilizirati mase i tako stvaraju teren za pojavu totalitarnih pokreta. Kao klasične primjere Neumann navodi nje- 


\section{Zaključak}

Problem terorizma i vjerskoga fundamentalizma danas nije samo dnevni red političkih donositelja odluka na svijetu. To je također problem s kojim se široko bave i različite društvene znanosti i filozofija. U članku je istražena jedna od temeljnih dimenzija akademske rasprave o terorizmu i upravo s dimenzijom odnosa koji postoje između terorističkih akcija i vjerskih doktrina, s posebnim naglaskom na doktrine islama. Pokazalo se da danas u islamskom svijetu postoji nekoliko struja islama, među kojima je jedna od struja s izravnim utjecajem na fenomen terorizma, a to je salafistička struja. Vidjelo se da politički salafizam kroz doslovno čitanje teksta Kurana pokuša dati vjerski temelj organizacijama koje provode terorističke aktivnosti, kao što su Al-Qaida i ISIS.

U članku se utvrdilo da džihad, sveti rat u islamu, i nasilje nad drugim vjerskim skupinama potencijalno postoje u surama Kurana, osobito kod onih koje pripadaju Muhamedovu proročanstvu u razdoblju u Medini. Zapaženo je da te sure svojim pozivima proturječe surama razdoblja proročanstva Muhameda u Meki, koje su više duhovnoga i tolerantnoga karaktera. Objasnilo se da ta proturječnost u Muhamedovu proročanstvu izražava različita stanja njegova odnosa s političkom, vojnom i vjerskom moći društva u kojem je živio i djelovao. U članku se također podupire teza Maxa Webera o islamu kao religiji ratnika. Argumentirali smo da jedina mogućnost izbjegavanja nasilnoga potencijala sadržanoga u kuranskom tekstu jest hegelovsko i kontekstualno čitanje toga teksta. Ukazali smo na to da takvo čitanje ponajprije podrazumijeva znanstvenu i filozofsku kritiku teksta i otkriće njegove antropogeneze. Naglasili smo da bijeg iz moralnoga epistemološkoga apsolutizma kuranskoga teksta čini intelektualni temelj na kojem se može graditi kultura pluralizma vrijednosti i vjerske tolerancije u kontekstu arapskih društva, naime jedne kulture koja čini antipod vjerskoga fanatizma, koji je uvijek sklon da se transformira u nasilje i u totalitarne projekcije u ljudskom društvu.

\section{Literatura:}

Beiser, Frederick C. (2011). The German Historicist Tradition. Oxford: The Oxford University.

Berdyaev, Nicolaj (1948). The Russian Idea. New York: Macmillan.

Biblija. Adalbert Rebić, Jerko Fućak i Bonaventura Duda (ur.), Jeruzalemska Biblija. Zagreb: Kršćanska sadašnjost, 1994.

Bonney, Richard (2004). Jihād: From Qur'ān to bin Laden. New York: Palgrave.

Buruma, Ian; Margalit, Avishai (2004). Occidentalism: The West in the Eyes of Its Enemies. New York: The Penguin Books.

Chaliand, Gérard; Blin, Arnaud (ur.), (2007). The History of Terrorism: From Antiquity to Al Qaida. Berkeley: University of California.

Childs, Peter (2000). Modernism. New York: Routledge.

mački nacional-socijalizam i talijanski fašizam. - Sklonost prihvaćanju teorija komplota danas dominira ideološkom pozadinom radikalnih pokreta u islamskom svijetu, čime je determiniran i njihov totalitarni karakter. 
Cory, Stephen (2009). Jihad. U: Juan Eduardo Campo (ur.), Encyclopedia of Islam (str. 397-398). New York: Facts on File.

Courtois, Stéphane; Werth, Nicolas; Panné, Jean-Louis; Paczkowski, Andrzej; Bartosek, Karel; Margolin, Jean-Louis (1999). The Black Book of Comunism: Crimes, Terror, Repression. Cambridge, MA: Harvard University.

Cox, Caroline; Marks, John (2002). The 'West', Islam and Islamism: Is ideological Islam compatible with liberal democracy? London: Civitas.

Foucault, Michel (1978). The History of Sexuality: Volume I: An Introduction. New York: Pantheon Books.

Gellner, Ernest (1988). Plough, Sword and Book: The Structure of Human History. Chicago: Chicago University.

Geoffroy, Eric (2010). Introduction to Sufism: The Inner Path of Islam. Bloomington: World Wisdom.

Habermas, Jürgen (1985). Der philosophische Diskurs der Moderne. Zwölf Vorlesungen. Frankfurt am Main: Suhrkamp Verlag.

Hallaq, Wael B. (1997). A History of Islamic Legal Theories: An Introduction to Sunni Usul al fiqh. Cambridge: Cambridge University.

Hallaq, Wael B. (2009). An Introduction to Islamic Law. Cambridge: Cambridge University.

Hashmi, S. H. (22016). Jihad. U: Richard C. Martin (ur.), Encyclopedia of Islam and the Muslim World (str. 583-586). New York: Gale.

Johnson, James Turner (1997). The Holy War Idea in the Western and Islamic Traditions. University Park: The Pennsylvania State University.

Kepel, Gilles (2008). Beyond Terror and Martyrdom: The Future of the Middle East. Cambridge, MA: Harvard University.

Khatab, Sayed (2006). The Political Thought of Sayyid Qutb: The Theory of Jahiliyyah. London: Routledge.

Kuran. Prevod značenja Kur'ana. Preveo Besim Korkut. Sarajevo: Starješinstvo Islamske zajednice u Bosni i Hercegovini, Hrvatskoj i Sloveniji, 1984.

Lewis, Bernard (1988). The Political Language of Islam. Chicago: The University of Chicago.

Lewis, Bernard (1994). Islam and the West. New York: Oxford University.

Löwith, Karl (1957). Meaning in History. Chicago: University of Chicago.

Marcuse, Herbert (1955). Reason and Revolution: Hegel and the Rise of Social Theory. London: Routledge.

Marx, Karl; Engels, Friedrick; Trotski, Leon; Wright, John G.; Lenin, V. I. (2001). Marxism versus Anarchism. S. 1.: Chipenedale.

Moïsi, Dominique (2009). The Geopolitics of Emotion: How Cultures of Fear, Humiliation and Hope are Reshaping the World. New York: Doubleday.

Mosse, George L. (2010). Toward a General Theory of Fascism. U: Constantin Iordachi (ur.), Comparative Fascist Studies: New perspectives (str. 60-94). London: Routledge.

Nechayev, Sergey (1869). The Revolutionary Catechism. URL: https://www.marxists.org/ subject/anarchism/nechayev/catechism.htm (14.10.2018.)

Neumann, Franz L. (1978). Wirtschaft, Staat und Demokratie. Frankfurt am Main: Suhrkamp Verlag.

Newby, Gordon (2002). A Concise Encyclopedia of Islam. Oxford: Oneworld.

Platon (1997). Laws. U: J. M. Cooper (ur.), Plato: Complete Works. Indianapolis: Hackett.

Ramadan, Tariq (2004). Western Muslims and the Future of Islam. New York: Oxord University.

Ramadan, Tariq (2012). Islam and the Arab Awakening. New York: Oxford University. 
Sloterdijk, Peter (2010). Rage and Time: A Psychopolitical Investigation. New Yoirk: Columbia University.

Spencer, Herbert (2009). First Principles. Cambridge: Cambridge University.

Waardenburg, Jacques (2002). Islam: Historical, Social and Political Perspectives. Berlin: Gruyter.

Weber, Max (1978). Economy and Society: An Outline of Interpretive Sociology. Berkeley: University of California.

Weeramantry, C. G. (1988). Islamic Jurisprudence: An International Perspective. Houndmills: Macmillan.

Žižek, Slavoj (2011). For Egypt, this is the miracle of Tahrir Square. The Guardian, 10. veljače. URL: https://www.theguardian.com/global/2011/feb/10/egypt-miracle-tahrir-square (14.10.2018.)

Žižek, Slavoj (2014). ISIS Is a Disgrace to True Fundamentalism. The New York Times, 3. rujna. URL: https://opinionator.blogs.nytimes.com/2014/09/03/isis-is-a-disgraceto-true-fundamentalism $/ ? \mathrm{hp} \&$ action $=$ click \&pgtype $=$ Homepage $\&$ module $=\mathrm{c}-\mathrm{co}-$ lumn-top-span-region\&region $=\mathrm{c}-$ column-top-span-region $\&$ WT.nav $=\mathrm{c}-$ columntop-span-region (14.10.2018.)

\section{On Contemporary Mainstream Islam, the Holy War and Reading the Quran}

Blerim Latifi*, Kristë Shtufi**

\section{Summary}

The horrifying massacres committed during the civil war in Syria and Iraq by different groups, particularly those fighting under the banner of ISIS (Islamic State of Iraq and Syria) brought together many scholars, clerics, Islamic theologians and others throughout the world in a discursive effort to find a connection between the Quran and the military practices of the militants of this state, the self-proclaimed new caliphate. They maintain firmly that neither justifications nor arguments can be found in the Quran for the crimes of ISIS, though militants declare that their deeds in Syria and Iraq are nothing more than a fulfillment of the Quran obligation which in Islam is known as jihad.

Who is in the right? In order to be able to answer this question, however inconclusive, one must dismantle a range of issues. The first involves the context of mainstream thinking in contemporary Islam. In order to resolve this issue we must ascertain what place groups, such as ISIS and Al Nusrat (which emerged as a branch of Al Qaeda) occupy in the typology and topology of Islamic doctrine. The second entails the concept of jihad, and ultimately the issue of the text of the Quran itself, its stance toward war and violence and also various possible interpretations of the text. The second and third questions enable us to envision the extent to which the pretensions of these groups of bringing about a reactualisation of authentic islam are tenable.

Key words: contemporary Islam, Quran, violence, Weber, Hegel, contextualization

* Blerim Latifi, Ph.D., Assistant Professor, Faculty of Philosophy, University of Pristina. Address: George W. Bush Street, 10000, Kosovo. E-mail: blerimlatifi5@gmail.com

** Kristë Shtufi, Ph.D., Assistant Professor, Faculty of Philosophy, University of Pristina. Address: George W. Bush Street, 10000 Pristina, Kosovo. E-mail: kriste.shtufi@uni-pr.edu 